\title{
Tedarik Zinciri Süreçlerinin Ölçüm ve İyileştirilmesinde Bir SCOR Modeli Uygulaması
}

\author{
Cengiz YILMAZ* $\quad$ Bahadır ATSAN**
}

Tuğba SARI***

\begin{abstract}
$\ddot{O} Z$
Tedarik zinciri, hammadde tedarik eden, onları ara mallara ve daha sonra nihai ürünlere dönüşürren ve ürünleri bir dağıtım sistemi aracılı̆̆ıyla müşterilere teslim eden bir tesisler ă̆ıdır. İsletmelerin yoğun rekabet ortamında, hedeflerine ulaşmaları, başarll bir şekilde planlanıp uygulanan entegre tedarik zinciri yönetimi ile mümkündür. Tedarik zinciri operasyonlarına bir referans oluşturmak üzere Tedarik Zinciri Konseyi tarafindan geliştirilen, SCOR modeli, yönetim süreçlerinin standart bir tanımını, standart süreçler arasındaki ilişkilerin bir çerçevesini, süreç performansını ölçmek için standart metrikleri, sınıfinın en iyisi performans üreten yönetim uygulamaların ve yazllım özelliklerine ve işlevlerine standart bir uyum içerir. Bu makalede bisiklet üretimi yapan bir işletmede, tedarikçi seçimini etkileyen faktörlerin belirlenmesi ve tedarikçi performansının değerlendirilmesi amacı ile tedarikçilerini kapsayan, ve SCOR metriklerini esas alan bir model oluşturulmuştur. Analiz sonuçlarına göre, ele alınan tedarik zincirinde, tedarikçi seçimi için en önemli faktörler sirasıyla "üründe değişim yapma esnekliği”, "teslimat süresinin azalması", ve "teslim süresi değişimine karşı esneklik" olarak sıralanabilir. Tedarikçi performansını en çok etkileyen faktörler ise, "iade ürünlerin izlenebilirliği ve "taahhüt edilen tarihe uygun sevkiyat" olarak belirlenmiștir.
\end{abstract}

Anahtar Kelimeler: SCOR, Tedarik Zinciri, Performans Değerlendirme, Tedarikçi Seçimi JEL Siniflandırması: M11

\section{A SCOR Model Implementation in the Measurement and Improvement of Supply Chain Processes}

\begin{abstract}
A supply chain is a network of facilities that supply raw materials, transform them into final products, and deliver products to customers through a distribution system. Developed by the Supply Chain Council to provide a reference to supply chain operations, the SCOR model provides a standard definition of management processes, a framework of relationships between standard processes, standard metrics to measure process performance, best-in-class performance management applications, and software features and functions. In this study, a model based on SCOR metrics is introduced to determine the factors affecting supplier selection and evaluate supplier performance. The model was applied to a bicycle producer company and its suppliers. The aim is to determine the factors affecting supplier selection and to evaluate supplier performance. According to the results of the study, the most important factors for supplier selection in the supply chain under consideration can be listed as "flexibility to change in products", "reduction in delivery time" and "flexibility to
\end{abstract}

\footnotetext{
*Prof.Dr. Konya Gıda ve Tarım Üniversitesi, Sosyal ve Beşeri Bilimler Fakültesi, Yönetim Bilişim Sistemleri Bölümü. cengiz.yilmaz@ gidatarim.edu.tr, ORCID Bilgisi: 0000-0002-7745-1710

** Manisa Celal Bayar Üniversitesi Sosyal Bilimler Enstitüsü. bahadiratsan@ hotmail.com ORCID Bilgisi:00000003-1075-7544

*** Dr.Öğretim Üyesi Konya Gıda ve Tarım Üniversitesi, Sosyal ve Beşeri Bilimler Fakültesi, Yönetim Bilişim Sistemleri Bölümü. tugba.sari@gidatarim.edu.tr ORCID Bilgisi: 0000-0002-9536-5541
}

(Makale Gönderim Tarihi: 06.03.2020 / Yayına Kabul Tarihi:17.10.2020)

Doi Number: 10.18657/yonveek.699836

Makale Türü: Araştırma Makalesi 
change in delivery time", respectively. The factors that affect supplier performance the most are determined as "traceability of returned products" and "on time delivery".

Key Words: SCOR, Supply Chain, Performance Evaluation, Supplier Selection,

JEL Classification: M11

\section{GİRIŞ}

Günümüz iş dünyasının yüksek rekabet ortamı, firmaları, müşteri talep ve beklentilerine karşı her zamankinden daha duyarlı olmaya zorlamaktadır. Firmalar, müşteri isteklerine göre tasarlanmış daha kaliteli ürün ve hizmetleri, rakiplerinden daha ucuza mal etmek ve bu ürün ve hizmetleri doğru zamanda ve doğru miktarda müşterilerine sunabilmek için büyük bir çaba sarf etmektedir. Bu yarış, firmaların tek başına rekabet edeceği bir platform yerine, başarılı ve sürdürülebilir bir şekilde müşteriler ve diğer tüm paydaşlar için değer yaratmanın yolu olan, tedarik zincirinin tüm üyelerinin bütünleşik ve ortak çabasını gerektirmektedir. Günümüzde yaşanan rekabet artık firmalar arasında değil, tedarik zincirleri arasındadır. Tedarik zincirinin etkin bir şekilde yönetilmesi ile zincir üyesi işletmeler arası belirsizlikler ortadan kalkmaktadır. Bu sayede stok, üretim, hammadde, taşıma ve dağıtım maliyetleri azalarak tüm zincir üyeleri için değer katacak ortak bir fayda sağlanmış olacaktır (Gürsoy, 2013:29).

Tedarik zinciri yönetiminde zincirdeki işletmelerin işbirliği ile gerçekleşen etkin bilgi ve malzeme akışları, kısıtlı kaynakların gereksiz kullanımını önlemekte ve zamandan tasarruf sağlamaktadır. Tedarik zincirinin verimli bir şekilde yönetilmesi bir takım avantajlar sağlamaktadır. $\mathrm{Bu}$ avantajlar Tedarik Zinciri Konseyi tarafından aşağıdaki şekilde belirtilmiştir (Sağlam, 2013:19).

- $\quad$ Girdilerin teminini garantileyerek, üretimin devamlılığını sağlaması

- Stoklarin azalmasi

- Tedarik süresinin kısalması ile pazardaki değişikliklere hızlı bir şekilde cevap verebilme ve teslimat performansının iyileşmesi

- Teknolojik gelişmelerden faydalanarak tahmin doğruluğunun artmasi

- Teknolojik gelişmelerin takip edilmesi ile yenilik teşviki sağlama

- Tüketici taleplerini en iyi şekilde karşılayarak zincir boyunca kalitenin ve verimliliğin artmas

- $\quad$ Zincir boyunca maliyetlerin düşmesi

Firmalar için tedarik zincirlerinin yüksek performansla yönetilmesi hayati önem arz etmektedir. Tedarik zinciri yönetiminde performans ölçümü için uygun performans metrikleri/ölçütleri/kriterleri seçilmelidir. Kritik başarı ölçütleri doğru ürün, miktar, zaman, yer, yüksek esneklik, minimum toplam maliyet, kısa çevrim süresi ve minimum stok düzeyi olarak sınıflandırılabilir (Kocaoğlu, 2009:9). Her işletmenin tedarik zinciri endüstri koluna göre değişiklik gösterdiği için performans değerleme kriterleri farklılık göstermektedir. Temelinde zincirin aynı amaç çerçevesinde toplanıp etkin bir şekilde yönetilmesi yatar. Zincirdeki her bir işletmenin performansı zincirin bütün performansını etkilemektedir. Performans ölçümü geleneksel tedarik zinciri yönetiminde finansal parametreler ile ölçülmektedir. Finansal ölçütlerin geçmişe odaklı olması ve finansal olmayan konuları değerlendirememesinden dolayı bu yaklaşım yetersiz kalmaktadır. $\mathrm{Bu}$ 
yetersizliklerin önüne geçebilmek için dengelenmiş skor kart yöntemi, SCOR modeli, aktivite bazlı maliyetlendirme ve ekonomik katma değer gibi yöntemler kullanılarak tedarik zinciri performans ölçümü modelleri geliştirilmiştir (Bilişik, 2012:12).

Tedarik Zinciri Konseyi tarafından geliştirilen SCOR (Supply Chain Operations Reference) modeli tedarik zinciri içinde talep tahmini sürecinden talebin karşılanmasına kadar bütün süreçleri içermektedir. Kurumsal karnenin aksine özellikle tedarik zinciri performans ölçümü amaçlı hazırlanmıştır (Bilişik, 2012:14). Başarılı bir şekilde süreç performans ölçümü yapması ve tedarik zincirini tüm yönleri ile tanımlayıp, kapsamlı bir ölçme ve değerlendirmeye imkan vermesi sebepleri ile bu çalışmada SCOR modeli kullanılmıştır.

$\mathrm{Bu}$ çalışmanın amacı bisiklet sektöründe faaliyet gösteren bir işletmenin tedarik zinciri performansının SCOR modeli uygulaması ile değerlendirilmesidir. Araştırma kapsamında işletmenin tedarik zinciri faaliyetlerinin özelliklerini belirleyen değişkenler arasındaki ilişkileri açıklayacak istatistiksel araştırmalar yapılmıştır. Değerlendirme soruları, performans metrikleri SCOR modeli V12.0 metrikleri baz alınarak hazırlanmış ve tedarik zinciri çalışanlarına yöneltilmiştir. Tedarikçi seçim kriterlerini etkileyen faktörler ve tedarikçi performansını değerlendirmeye yönelik sorular 5'li Likert ölçeği ile derecelendirilmektedir. Faktör analizi öncesi, verilerin faktör analizine uygunluğu Kaiser-Meyer-Olkin (KMO) testi ve örneklem yeterliliği Bartlett Küresellik testi ile ölçülmüştür. Analiz sonucunda tedarikçi seçimini etkileyen faktörlere faktör analizi uygulanmıştır. Bağımsız değişkenlerin piyasa çalışma durumuna göre etkisi t-testi analizi ile irdelenmiş, sektörel bazda tedarikçi seçim faktörleri ise tek yönlü Anova tekniği ile analiz edilmiştir.

Çalışmanın bölümleri sırasıyla aşağıdaki gibidir: Birinci bölüm SCOR modeli uygulamalarına ilişkin kapsamlı bir literatür taramasını içermektedir. Çalışmanın ikinci bölümünde SCOR modeli ile ilgili teorik bilgiler verilmiştir. Üçüncü bölüm olan bir sonraki bölüm SCOR modelinin tedarik zinciri performansını değerlendirmek üzere uygulanması ve elde edilen verilerin analiz edilmesi süreçlerini içermektedir. Son bölüm sonuç bölümünde çalışmanın sonuçları ve çalışmaya ilişkin öneriler tartışılmıştır.

\section{LITERATÜR TARAMASI}

Literatürde, tedarik zinciri yönetiminde SCOR modelinin kullanımını araştıran pek çok çalışma bulunmaktadır. Bu çalışmaların ortak özelliği SCOR modelinin kapsamlı yapısı sayesinde pek çok farklı ihtiyaca cevap verebilmesi ve çok kriterli karar verme yöntemleri veya büyük veri analizi gibi güncel yöntemlerle bütünleşik kullanılabilme özelliğidir. Aşağıda bu konuda yazılmış makalelerden örnekler verilmiştir:

Lockamy and McCormack (2004), SCOR metriklerinin tedarik zinciri performansı üzerindeki etkilerini araştırdıkları çalışmalarında, planlama sürecinin, diğer tüm alanlar için büyük önem taşıdığı sonucuna ulaşmışlardır. Çalışmanın diğer sonuçları arasında, işbirliğinin planlama tedarik ve imalat alanlarında önemli olduğu, takım çalışmasının en çok planlama ve tedarik alanlarında gerektiği, ve 
dağıtım kararlarında süreç ölçüleri, süreç kredibilitesi, süreç entegrasyonu ve bilgi teknolojilerinin en kritik maddeler olduğu yer almaktadır.

Persson'ın (2011) SCOR metriklerini baz alarak, İsveç’te üretim yapan küresel bir işletmede uyguladığı çalışması, değer akış haritalaması ile elde edilen verinin, bir ürünün tedarik zinciri süreçlerinde kullanılması ile farklı senaryoları simülasyon yolu ile test ettiği, dinamik bir tedarik zinciri analizi aracı sunar.

Ganga and Carpinetti (2011) tedarik zinciri performansının ölçülmesinde SCOR modeli metriklerinin arasındaki nedensel ilişkileri tahmin eden, bulanık mantık temelli bir model önerir. Bu çalışmanın diğer çok kriterli karar verme tekniklerine göre başlıca avantajı, belirsizlik altında verecekleri kararlarda yöneticilere yardımcı olmasıdır.

Zhou vd. (2011) 125 Amerikan imalatçı işletmeden topladığı verilerle SCOR modelinde yer alan tedarik zinciri süreçleri yapısını araştırmış ve aşağıdaki sonuçlara ulaşmıştır: (1) Planlama süreci, tedarik, imalat ve dağıtım süreçleri üzerinde anlamlı ve olumlu etkiye sahiptir. (2) Tedarik süreci, imalat süreci üzerinde önemli bir olumlu etkiye sahiptir. (3) İmalat süreci, dağıtım süreci üzerinde önemli bir etkiye sahiptir.

Li vd. (2011), ISO 9000 sertifikasına sahip 232 işletmenin tedarik zinciri yönetiminde, SCOR modeli kalite güvence göstergelerini temel alan bir anket çalışması gerçekleştirmiştir. Çalışmanın bulgularına göre, tüm karar alanları tedarik zinciri performansı üzerinde pozitif etkiye sahip görülmekle birlikte, müşteri odaklı tedarik zinciri kalitesinde özellikle planlama ve tedarik kararları, firma odaklı yaklaşımda ise üretim kararı ön plana çıkmaktadır.

Palma-Mendoza 2014 tarihli çalışmasında, tedarik zincirinin yeniden yapılandırılması sirasında, SCOR metriklerine dayanan performans kriterlerinin değerlendirilmesi için bir diğer çok kriterli karar verme yöntemi olan Analitik Hiyerarşi Prosesinden yararlanmıştır. Böylelikle tedarik zincirinin yeniden tasarımında, hangi tedarik zinciri süreçlerinin anahtar rol oynadığ 1 analitik olarak belirlenmiştir.

Ntabe vd.'nin 2015 tarihli makalesi, SCOR modelinin tedarik zincirlerinde Yeşil SCOR modeli uygulanabilirliğini ve dolayısıyla, çevresel etki ve dönüşüm süreci için ne ölçüde kullanıldığını araştırır. Çalışmadan çıkan sonuç, SCOR modelinin, tedarik zincirinin finansal performansını değerlendirmede elverişli olduğu kadar, çevresel etki değerlendirmede de karar destek modeli olarak yararlı olabileceği yönündedir.

Lima-Junior ve Carpinetti (2016), tedarikçi seçimi problemi için SCOR modeli ile bulanık TOPSIS yöntemini birleştirmişlerdir. Oluşturdukları modele temel olarak maliyet ve dağıtım performansı kriterlerini dahil eden yazarlar, tedarik zincirinin diğerleri ile kıyaslanmasına olanak veren, karar süreçlerinin çevikliğine katkıda bulunan, alternatif sayısında kısıtlama içermeyen ve mevcut sisteme yeni tedarikçilerin eklenmesine olanak veren bir tedarikçi seçim modeli oluşturmuşlardir.

Dissanayake ve Cross (2018), tedarik zinciri performansının ölçülmesi için hangi kriterlerin daha önemli olduğu sorusuna, SCOR modeli metriklerini temel 
alarak oluşturdukları modelin değişkenlerini AHP ve SEM yöntemleri ile analiz ederek cevap aramışlardır. Çalışmanın sonuçlarına göre, varlık yönetimi her iki yöntemle de en önemli kriter olarak belirlenmiştir.

Wang vd. (2018) SCOR metrikleri, AHP ve TOPSIS yöntemlerini bütünleştirdikleri çalışmalarında, tedarikçi değerlendirme ve seçimi için hibrit bir model önermişlerdir. SCOR metriklerinden güvenilirlik, yanıt verebilirlik, çeviklik, maliyet ve varlıklar kriterlerini temel alan bu model, petrol endüstrisinde faaliyet gösteren bir firma üzerinde uygulanmıştır.

Chehbi-Gamura vd. (2019), SCOR modeli temelinde tedarik zinciri yönetiminde Büyük Veri Analitiğinin önemine dikkat çeken bir literatür taraması gerçekleştirmiştir. Bu çalışma sonucunda öne çıkan öneri; yöneticilerin, bireysel olarak veri toplayıp işlemek gibi maliyetli bir çaba yerine, tüm tedarik zinciri boyunca değerli verinin yaratılması için ortak efor sergilemeleri gerekliliğidir.

\section{METODOLOJI}

SCOR referans modeli tedarik zincirini standartlaştırmak, süreç gelişiminde alt yapı oluşturmak, zincir performansında sektörel karşılaştırmalar yapmak, zincirin iletişim ve bilişim sistemlerini değerlendirmek, rekabetçi üstünlük sağlamak amacıyla geliştirilmekte ve uygulanmaktadır. Tedarik Zinciri Konseyi tarafindan 1996 yılında geliştirilen SCOR modeli iş uygulamalarındaki değişikliklere uyum sağlamak amacıyla düzenli olarak güncellenmiştir (Apics, 2017a). Apics (Association for Supply Chain Management) ve Tedarik Zinciri Konseyi'nin 2014 yılında birleşmesi ile Apics tarafından güncellenmeye başlamış ve günümüzdeki son halini 12. versiyon ile almıştır. Son güncelleme ile modelde artık altı temel süreç bulunmaktadır: (1) Planlama (Plan), (2) Tedarik (Source), (3) Üretim (Make), (4) Dağıtım (Deliver), (5) İade (Return) ve (6) Mümkün Kılma (Enable) (Abou El Majd vd., 2018:2). SCOR modeli siparişin alınmasından ödenmesine kadar sipariş boyunca müşteri ilişkilerini, malzeme, yedek parça, yazılım gibi fiziksel malzemeleri ve talep tahmininden siparişin ulaşmasına kadar bütün pazar faaliyetlerini altı temel süreç kapsamında ölçmektedir (Kocaoğlu, 2009:51). Bu süreçler Şekil 1.'de görülebilir.

Şekil 1. Altı temel SCOR süreci

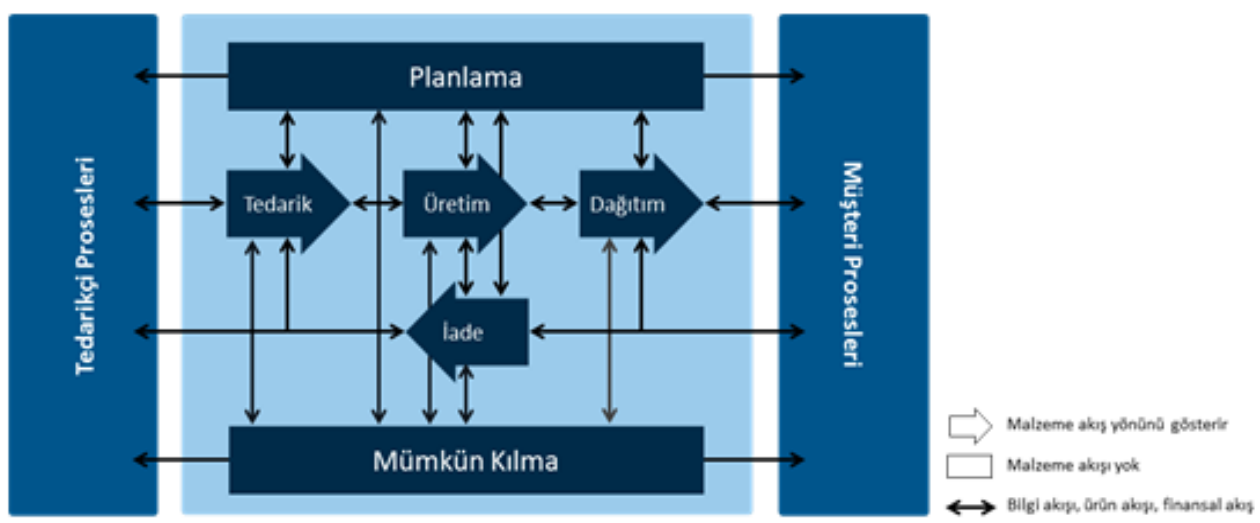

Kaynak: (Apics, 2017b) 


\section{A. SCOR Modeli Seviyeleri}

SCOR modeli yapısal olarak incelendiğinde aşağıda listelenen seviyelerden oluştuğu görülmektedir:

- Seviye 1 (Üst Seviye - Süreç Tipleri)

- Seviye 2 (Yapılandırma Seviyesi - Süreç Kategorileri)

- Seviye 3 (Süreç Elemanı Seviyesi - Süreç Ayrıştırma)

- Seviye 4 ve daha alt seviyeler $(5,6, \ldots)$ (Uygulama Seviyesi - Ayrıştırılmış Süreç Elemanları)

İlk seviye süreç tiplerini tanımlayan Seviye 1'dir. Seviye 1; plan, tedarik, üretim, dağıtım, iade ve mümkün kılma süreçleri ile ilgili genel tanımlamalar yaparak tedarik zinciri rekabetçi amaç fonksiyonunu tanımlar. Seviye 2, süreç yapılandırma seviyesidir. Temel proses kategorilerini daha ayrıntılı bir şekilde süreç tiplerine göre tanımlamıştır. Süreç eleman seviyesi olan Seviye 3, seçilen pazarlarda başarılı bir şekilde rekabet edebilmek için, iş süreçlerinin tanımlarının yapıldı ̆̆ı, girdi ve çıktıların belirlendiği seviyedir. Son olarak rekabetçi avantajı sağlama ve değişen pazar koşullarına adapte olabilmek için gerekli pratikler her işletmenin kendine özgüdür ve tedarik zinciri yönetimi detay süreçleri Seviye 4 ve üstü seviyelerde belirlenir (Tunçbilek, 2012:21).

\section{B. SCOR Modeli Performans Kriterleri ve Metrikleri}

Tedarik zincirinin değerlendirilmesi, eksikliklerinin giderilerek iyileştirilmesi, işletmenin kendini tanıması, müşterilerin gözünden işletmelerin tanınması ve endüstrideki diğer işletmelerle kıyas yapması için önemli bir adımdır. SCOR modeli performansının ölçülmesi için kullanılan metrikler, süreç performans ölçümü için kullanılan ve modelde tanımlanan standart metrikler içerir (Tunçbilek, 2012:27). Seviye 1'den seviye 3'e kadar hiyerarşik bir yap1 içinde düzenlenmiş 250'den fazla SCOR metriği vardır (Apics, 2018).

SCOR modelinde yer alan performans nitelikleri (performance attributes); güvenilirlik (reliability), yanıt verebilirlik (responsiveness), çeviklik (agility), maliyet (costs) ve varlık yönetimi verimliliği (asset management efficiency) şeklinde beşe ayrılır. İlk üç özellik müşteri odaklılık- dış odaklı olarak kabul edilirken son ikisi iç odaklı - işletme içi odaklı olarak değerlendirilmektedir. Tablo 1, performans özelliklerini ve tanımlarını içeren bir tablo şeklinde sunulmuştur (Apics, 2018).

Tablo 1. SCOR performans nitelikleri

\begin{tabular}{|l|l|}
\hline Performans Özellikleri & \multicolumn{1}{c|}{ Tanım } \\
\hline Güvenilirlik (Reliability) & $\begin{array}{l}\text { Görevlerin beklendiği gibi gerçekleştirilme yeteneğidir. Güvenilirlik özelliği için } \\
\text { ölçütler: Doğru ürünün, doğru zamanda, doğru miktar, doğru kalitede doğru } \\
\text { müşteriye teslimat performansının belirlenmesi. }\end{array}$ \\
\hline $\begin{array}{l}\text { Yanıt verebilirlik } \\
\text { (Responsiveness) }\end{array}$ & $\begin{array}{l}\text { Bir tedarik zincirinde, görevlerin gerçekleştirilme hızıdır. Örneğin, müşteriye } \\
\text { ürüleri sağlama hızı. }\end{array}$ \\
\hline Çeviklik (Agility) & $\begin{array}{l}\text { Rekabet avantajı kazanmak veya sürdürebilmek için dış etkilere cevap verme, } \\
\text { piyasaya cevap verme yeteneğidir. Esneklik ve Uyarlanabilirliği içerir. }\end{array}$ \\
\hline \multirow{2}{*}{ Maliyet (Costs) } & $\begin{array}{l}\text { Tedarik zinciri işlemlerinin maliyetidir. Buna işgücü maliyetleri, malzeme } \\
\text { maliyetleri, yönetim ve nakliye maliyetleri de dahildir. Tipik bir maliyet ölçütü } \\
\text { Satılan Malın Maliyetidir. }\end{array}$ \\
\hline \multirow{2}{*}{ Varlıklar (Assets) } & $\begin{array}{l}\text { Varlıkların verimli bir şekilde kullanılabilmesi yeteneğidir. Bir tedarik zincirindeki } \\
\text { varlık yönetimi stratejileri, stokların azaltılması ve dış kaynak kullanımıdır. } \\
\text { Ölçütleri: Envanter ve kapasite kullanımı. }\end{array}$ \\
\hline
\end{tabular}

Kaynak: (Apics, 2018) 
Seviye 1 metrikleri, doğru kurulmuş bir tedarik zinciri yapısını tanımlar. $\mathrm{Bu}$ ölçümlere aynı zamanda anahtar performans göstergeleri (KPI) de denmektedir (Tunçbilek, 2012:27). Bir işletmenin rekabetçi pazarlarda istediği pozisyona ulaşmada ne kadar başarılı olduğunu ölçebildiği metriklerdir (Apics, 2017a). Seviye 2 metrikleri, Seviye 1 metriklerindeki performans farklarının kök nedenlerinin belirlenmesini sağlar. Hiyerarşik olarak devam eden bu süreçte seviye 3 metrikleri, seviye 2 metriklerindeki performans farklarının kök nedenlerinin belirlenmesini sağlar (Tunçbilek, 2012:27). Seviye 1 için 5 farklı kategoride toplanan 10 farklı performans ölçümlemesi verilmiştir. Tablo 2, bu metrikleri ve karşıllı̆ındaki performans niteliklerini göstermektedir (Ağar, 2010:36).

Standartta kullanılan metriklerin kodları, performans niteliklerini gösteren iki harf ile başlar (Apics, 2017a):

- Güvenilirlik - RL (Reliability)

- Yanit verebilirlik - RS (Responsiveness)

- Çeviklik - AG (Agility)

- Maliyet - CO (Cost)

- Varlık Yönetimi - AM (Asset Management).

Ardından Seviye'nin belirtildiği bir sayı ve tanımlayıcı ifadesi gelir. Örnek olarak Mükemmel Sipariş Karşılama Oran1 - RL.1.1, Seviye 1 metriği olduğunu göstermektedir. Mükemmel durum - RL.2.4, Seviye 2'nin güvenilirlik metriği olarak örneklendirilebilir.

Tablo 2. Seviye 1 Metrikleri ve Performans Nitelikleri

\begin{tabular}{|c|c|c|c|c|c|}
\hline \multicolumn{2}{|c|}{$\begin{array}{l}\text { Performans } \\
\text { Nitelikleri }\end{array}$} & $\begin{array}{l}\text { Seviye } 1 \\
\text { Metrikleri }\end{array}$ & Kod & Tanımlama & Formülasyon \\
\hline \multirow{5}{*}{ 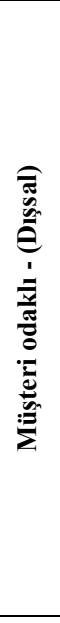 } & $\begin{array}{l}\text { Tedarik } \\
\text { zinciri } \\
\text { teslimat } \\
\text { güvenilirliği }\end{array}$ & $\begin{array}{l}\text { Mükemmel } \\
\text { Sipariş } \\
\text { Karşılama } \\
\text { Oranı }\end{array}$ & RL.1.1 & $\begin{array}{l}\text { Siparişlerin zarar } \\
\text { olmadan tam ve } \\
\text { doğru belgelerle } \\
\text { tamamlanması }\end{array}$ & $\begin{array}{l}\text { (Zamanında ve bütünüyle } \\
\text { ulaştırılan siparişler - Hatalı } \\
\text { dökümana sahip siparişler - } \\
\text { Taşıma hasarlı siparişler) } \\
\text { / Alınan toplam sipariş sayısı }\end{array}$ \\
\hline & $\begin{array}{l}\text { Tedarik } \\
\text { zinciri yanıt } \\
\text { verebilirliği }\end{array}$ & $\begin{array}{l}\text { Teslimat } \\
\text { Performansı } \\
\text { Oranı }\end{array}$ & RS.1.1 & $\begin{array}{l}\text { Siparişlerin müşteri } \\
\text { isteklerine göre } \\
\text { doğru zaman ve } \\
\text { miktarda ulaşması }\end{array}$ & $\begin{array}{l}\text { Zamanında sevk edilen müşteri } \\
\text { siparişleri sayısi/Toplam müşteri } \\
\text { siparişleri }\end{array}$ \\
\hline & \multirow{3}{*}{$\begin{array}{l}\text { Tedarik } \\
\text { zinciri } \\
\text { esnekliği }\end{array}$} & $\begin{array}{l}\text { Üst Tedarik } \\
\text { Zinciri } \\
\text { Esnekliği }\end{array}$ & AG.1.1 & $\begin{array}{l}\text { Zincirin olağan dış1 } \\
\text { talep } \\
\text { değişikliklerine } \\
\text { yanıt verme süresi }\end{array}$ & $\begin{array}{l}\text { (Siparişin gerçekleşme süresi) + } \\
\text { (tedarik çevrim süresi) }\end{array}$ \\
\hline & & $\begin{array}{l}\text { Üst Tedarik } \\
\text { Zinciri } \\
\text { Uygulanırlığ }\end{array}$ & AG.1.2 & \multirow{2}{*}{$\begin{array}{l}\text { Talep değişikliğine } \\
\text { karşı üretim } \\
\text { faaliyetleri } \\
\text { esnekliği }\end{array}$} & $\begin{array}{l}\text { Üst esneklik - plan diş1 \%20'lik } \\
\text { artış1 karşılama süresi }\end{array}$ \\
\hline & & $\begin{array}{l}\text { Alt Tedarik } \\
\text { Zinciri } \\
\text { Uygulanırlığ1 }\end{array}$ & AG.1.3 & & $\begin{array}{l}\text { Alt esneklik - } 30 \text { günde } \\
\text { siparişlerin azalma \%'si }\end{array}$ \\
\hline \multirow{2}{*}{ 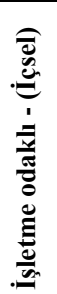 } & \multirow{2}{*}{$\begin{array}{l}\text { Tedarik } \\
\text { zinciri } \\
\text { maliyeti }\end{array}$} & $\begin{array}{l}\text { Toplam } \\
\text { Tedarik } \\
\text { Zinciri } \\
\text { Yönetim } \\
\text { Maliyeti } \\
\end{array}$ & CO.1.1 & $\begin{array}{l}\text { Planlama, tedarik } \\
\text { ve teslimatın } \\
\text { doğrudan ve } \\
\text { dolaylı maliyetleri }\end{array}$ & $\begin{array}{l}\text { Tedarik zincirine bağlı toplam } \\
\text { finans, planlama, envanter } \\
\text { taşma, malzeme alımı ve sipariş } \\
\text { yönetimi maliyetleri / Toplam } \\
\text { gelir }\end{array}$ \\
\hline & & $\begin{array}{l}\text { Sat1lan Ürün } \\
\text { Maliyeti }\end{array}$ & CO.1.2 & $\begin{array}{l}\text { Ürün veya hizmet } \\
\text { üretimi maliyeti }\end{array}$ & $\begin{array}{l}\text { Başlangıç envanter değeri }+ \\
\text { Üretilmiş ürünlerin maliyeti - } \\
\text { Bitiş envanter değeri }\end{array}$ \\
\hline
\end{tabular}


Cengiz Yılmaz \& Bahadır Atsan \& Tuğba Sarı / Tedarik Zinciri Süreçlerinin Ölçüm ve İyileştirilmesinde Bir SCOR Modeli Uygulaması

\begin{tabular}{|c|c|c|c|c|}
\hline \multirow{3}{*}{$\begin{array}{l}\text { Tedarik } \\
\text { zinciri varlık } \\
\text { yönetimi }\end{array}$} & $\begin{array}{l}\text { Nakitten } \\
\text { nakite çevrim } \\
\text { süresi }\end{array}$ & AM.1.1 & $\begin{array}{l}\text { Nakdin ürün ve } \\
\text { hizmetlere } \\
\text { yatırılması ile } \\
\text { yatırımın nakit } \\
\text { ürettiği zaman } \\
\text { sürekliliği }\end{array}$ & $\begin{array}{l}\text { Stok gün sayısı + Yapılacak } \\
\text { satış tahsilatlarının vadesi - } \\
\text { Satınalma borçlarını ödeme } \\
\text { süresi }\end{array}$ \\
\hline & $\begin{array}{l}\text { Duran } \\
\text { Varlıkların } \\
\text { Geri Dönüşü }\end{array}$ & AM.1.2 & $\begin{array}{l}\text { Faaliyetlerin } \\
\text { sürdürülmesi için } \\
\text { yatırım yapılan } \\
\text { duran varlık geri } \\
\text { dönüşü }\end{array}$ & $\begin{array}{l}\text { Duran varlık geliri / Net toplam } \\
\text { varlıklar }\end{array}$ \\
\hline & $\begin{array}{l}\text { İşletme } \\
\text { Sermayesi } \\
\text { Geri Dönüşü }\end{array}$ & AM.1.3 & $\begin{array}{l}\text { Toplam kullanılan } \\
\text { sermayenin } \\
\text { döndürülmesi }\end{array}$ & $\begin{array}{l}\text { Toplam ürün geliri / Net toplam } \\
\text { varlıklar }\end{array}$ \\
\hline
\end{tabular}

Kaynak: (Apics, 2017c)

\section{SCOR MODELII UYGULAMASI}

Uygulama bisiklet sektöründe faaliyet gösteren bir firmada yapılmıştır. Bisiklet sezonunda doğru modellerin doğru zamanında üretilmesi önemlidir. Tedarik Zinciri Yönetimi kapsamında en uygun fiyata en kaliteli hammadde tedariki ile kaliteli ürün üretip müşteri memnuniyetini sağlamak amaçlanmaktadır. Yaklaşı 100 tedarikçi ile çalışılmakta olup, karş11klı güven ortamında uzun dönemli işbirliklerinin kurulması sağlanmıştır. Bu kapsamda kurulan ortaklıklarda güven, zamanında teslimat, kalite ve fiyat önem arz etmektedir. Her işletmede tedarikçilerin teslimatında zaman konusunda sıkıntılar görülmektedir. Daha iyi bir iletişim, tedarik zincirinde entegrasyon, sürdürülebilir tedarikçi ilişkileri yönetimi için tedarik zincirinde SCOR modeli kapsamında performans ölçümü değerlendirmesi yapılmıştır.

\section{A. Bisiklet Tedarik Zinciri Uygulaması}

$\mathrm{Bu}$ araştırma kapsamında bisiklet üreticisinde tedarik zinciri faaliyetleri özelliklerini belirleyen değişkenler arasındaki ilişkileri açıklayacak istatistiksel analizler SPSS 24.0 paket programı kullanılarak yapılmıştır. Değerlendirme soruları, performans metrikleri SCOR modeli V12.0 baz alınarak hazırlanmış ve 31 tedarikçi firma için tedarik zinciri çalışanlarına yöneltilmiştir. Amaç, bisiklet firmasında tedarik zinciri yönetiminde tedarikçileriyle kurduğu ilişkilerin ve kriterlerin ne derece uygulandığını belirleme ve performansın değerlendirilmesidir. Araştırma kapsamında kullanılan değerlendirme formunda toplam 27 soru bulunmaktadır. Form, 3 bölümden oluşmaktadır. İlk bölümde tedarikçi firma ile ilgili bilgi veren 5 soru yer almaktadır. İkinci bölümde bulunan 12 soru ile tedarikçi seçim kriterlerini etkileyen faktörler ile son bölümde yer alan tedarikçi performansını değerlendirmeye yönelik 10 soru 5'li likert ölçeği (1: hiç etkilemez, 2: etkilemez, 3: ne etkiler ne etkilemez, 4: etkiler, 5: çok etkiler) ile derecelendirilmektedir. Araştırmada takip edilen aşamalar şekil 2'de gösterilmiştir. 
Şekil 2. Araştırma kapsamında izlenen yol haritası

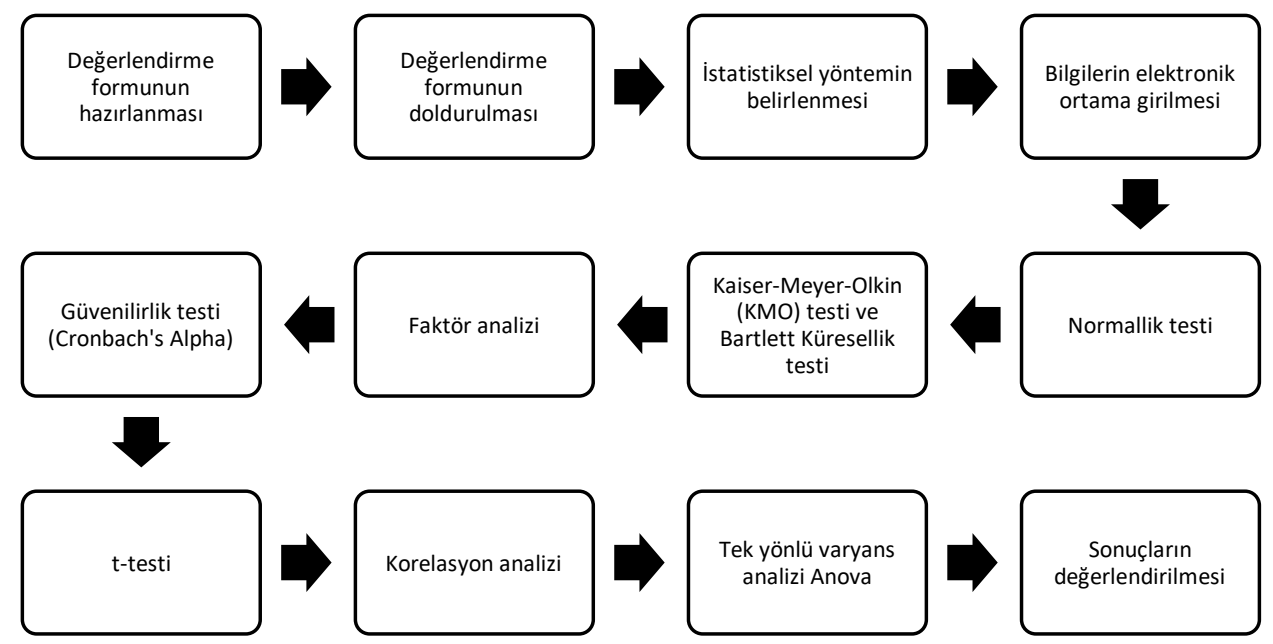

Tablo 3. Tedarikçi Firma Bilgileri

\begin{tabular}{|c|c|c|c|}
\hline & Değişken & Frekans & $\%$ \\
\hline \multirow{8}{*}{$\begin{array}{l}\text { Tedarikçi firma hangi sektörde faaliyet } \\
\text { göstermektedir? }\end{array}$} & Alüminyum & 2 & 6,5 \\
\hline & Etiket & 3 & 9,7 \\
\hline & Kadro & 1 & 3,2 \\
\hline & Kağıt-Karton & 2 & 6,5 \\
\hline & Bisiklet Aksesuarları & 13 & 41,9 \\
\hline & Lastik & 6 & 19,4 \\
\hline & Sele & 4 & 12,9 \\
\hline & Toplam & 31 & 100,0 \\
\hline \multirow{5}{*}{ Ürün çeşitliliği? } & $1-2$ & 23 & 74,2 \\
\hline & $3-5$ & 1 & 3,2 \\
\hline & $5-7$ & 3 & 9,7 \\
\hline & $>11$ & 4 & 12,9 \\
\hline & Toplam & 31 & 100,0 \\
\hline \multirow{3}{*}{ Piyasaya çalışma durumu? } & İç Piyasa & 6 & 19,4 \\
\hline & Dış Piyasa & 25 & 80,6 \\
\hline & Toplam & 31 & 100,0 \\
\hline \multirow{3}{*}{$\begin{array}{l}\text { Fiyat tedarikçi seçiminde en önemli } \\
\text { faktördür. }\end{array}$} & Evet & 22 & 71,0 \\
\hline & Hayır & 9 & 29,0 \\
\hline & Toplam & 31 & 100,0 \\
\hline \multirow[t]{2}{*}{ Uzun vadeli ilişkiler tercih sebebidir? } & Evet & 31 & 100,0 \\
\hline & Toplam & 31 & 100,0 \\
\hline
\end{tabular}

Birinci bölümde yer alan ve tedarikçi firma bilgilerini içeren temel betimleyici istatistiklere Tablo 3 'de yer verilmiştir. Bu çalışma kapsamında ana hammadde tedarikçilerinden 31 firma arasında yapılan değerlendirme kapsamında incelenen firmaların \%41,9'u bisiklet aksesuarı tedarikçisidir. 31 firma arasından 23 'ünün sunduğu ürün miktarı 1-2 arasındadır. Dış piyasa ağırlıklı tedarikçiler çoğunlukta incelenmiş olup, uzun vadeli kalıcı ilişkiler kurulması tercih sebebidir. Uygun fiyatlı hammadde tedariki, tedarikçi seçiminde önemli bir faktör olarak tespit edilmiştir. Değerlendirilen tedarikçiler arasında sunulan ürünler açısından 1- 
2 ürün çeşitliliğine sahip sektör bisiklet aksesuarları ve lastik olarak görülmektedir. Sektörel bazda piyasanın dış piyasa ağırlıklı olduğu ve bisiklet aksesuarı tedarikinde daha çok ithalattan yararlanıldığg görülmektedir.

Firmalara "Kalite", "Fiyat", "Ürünlerin miktarının doğru teslimi" gibi, SCOR modelinde çeşitli seviyelerde temsil edilen kriterlerin tedarikçi seçimini etkileme dereceleri sorulmuştur. Sonuçlar 1-5 likert ölçeğinde değerlendirilmiştir. Buna göre 1-hiç etkilemez, 5-çok etkiler kararını temsil etmektedir. Sorulan 11 kriter arasında "Üründe değişiklik yapma esnekliği” \%32,3 oran ile tedarikçi seçimi kararını en çok etkileyecek faktör olarak karşımıza çıkmaktadır. Bu faktörü \% 22,6 ile "Fiyat" faktörü takip etmektedir. Söz konusu faktörler ve frekansları Tablo 4. 'de sıralanmıştır.

Tablo 4. Tedarikçi Seçimini Etkileyen Faktörler

\begin{tabular}{|c|c|c|c|c|c|c|c|}
\hline & & $\begin{array}{c}\text { Hiç } \\
\text { Etkilemez }\end{array}$ & Etkilemez & $\begin{array}{l}\text { Ne } \\
\text { Etkiler, } \\
\text { Ne } \\
\text { Etkilemez }\end{array}$ & Etkiler & $\begin{array}{c}\text { Çok } \\
\text { Etkiler }\end{array}$ & Ortalama \\
\hline \multirow{2}{*}{ Kalite? } & Frekans & 0 & 1 & 6 & 21 & 3 & \multirow{2}{*}{3,84} \\
\hline & $\%$ & $0,0 \%$ & $3,2 \%$ & $19,4 \%$ & $67,7 \%$ & $9,7 \%$ & \\
\hline \multirow{2}{*}{ Fiyat? } & Frekans & 1 & 2 & 8 & 13 & 7 & \multirow{2}{*}{3,74} \\
\hline & $\%$ & $3,2 \%$ & $6,5 \%$ & $25,8 \%$ & $41,9 \%$ & $22,6 \%$ & \\
\hline \multirow{2}{*}{ Coğrafi yakınlık? } & Frekans & 25 & 0 & 0 & 6 & 0 & \multirow{2}{*}{1,58} \\
\hline & $\%$ & $80,6 \%$ & $0,0 \%$ & $0,0 \%$ & $19,4 \%$ & $0,0 \%$ & \\
\hline \multirow{2}{*}{$\begin{array}{c}\text { Tedarikçinin } \\
\text { üretim tesislerinin } \\
\text { teknolojik } \\
\text { gelişmişliği? }\end{array}$} & Frekans & 0 & 0 & 23 & 8 & 0 & \multirow[b]{2}{*}{3,26} \\
\hline & $\%$ & $0,0 \%$ & $0,0 \%$ & $74,2 \%$ & $25,8 \%$ & $0,0 \%$ & \\
\hline \multirow{2}{*}{ Zamanında teslim? } & Frekans & 0 & 20 & 2 & 8 & 1 & \multirow{2}{*}{2,68} \\
\hline & $\%$ & $0,0 \%$ & $64,5 \%$ & $6,5 \%$ & $25,8 \%$ & $3,2 \%$ & \\
\hline \multirow{2}{*}{$\begin{array}{l}\text { Teslimat süresinin } \\
\text { azalması? }\end{array}$} & Frekans & 1 & 3 & 21 & 6 & 0 & \multirow{2}{*}{3,03} \\
\hline & $\%$ & $3,2 \%$ & $9,7 \%$ & $67,7 \%$ & $19,4 \%$ & $0,0 \%$ & \\
\hline \multirow{2}{*}{$\begin{array}{l}\text { Öngörülemeyen } \\
\text { talep } \\
\text { değişkenliklerine } \\
\text { karşı esneklik? }\end{array}$} & Frekans & 1 & 0 & 18 & 12 & 0 & \multirow[b]{2}{*}{3,32} \\
\hline & $\%$ & $3,2 \%$ & $0,0 \%$ & $58,1 \%$ & $38,7 \%$ & $0,0 \%$ & \\
\hline \multirow{2}{*}{$\begin{array}{l}\text { Öngörülemeyen } \\
\text { teslim süresi } \\
\text { değişimime karşı } \\
\text { esneklik? }\end{array}$} & Frekans & 2 & 2 & 18 & 9 & 0 & \multirow[b]{2}{*}{3,10} \\
\hline & $\%$ & $6,5 \%$ & $6,5 \%$ & $58,1 \%$ & $29,0 \%$ & $0,0 \%$ & \\
\hline \multirow{2}{*}{$\begin{array}{c}\text { Ürünlerin } \\
\text { miktarlarının doğru } \\
\text { teslimi }\end{array}$} & \begin{tabular}{|l|} 
Frekans \\
\end{tabular} & 2 & 0 & 15 & 13 & 1 & \multirow[b]{2}{*}{3,35} \\
\hline & $\%$ & $6,5 \%$ & $0,0 \%$ & $48,4 \%$ & $41,9 \%$ & $3,2 \%$ & \\
\hline \multirow[t]{2}{*}{$\begin{array}{l}\text { Üründe değişiklik } \\
\text { yapma esnekliği? }\end{array}$} & Frekans & 8 & 9 & 1 & 3 & 10 & \multirow{2}{*}{2,94} \\
\hline & $\%$ & $25,8 \%$ & $29,0 \%$ & $3,2 \%$ & $9,7 \%$ & $32,3 \%$ & \\
\hline \multirow{2}{*}{$\begin{array}{c}\text { Ürün ve hizmet } \\
\text { performansı } \\
\text { arttırma } \\
\text { faaliyetleri? }\end{array}$} & \begin{tabular}{|l|} 
Frekans \\
\end{tabular} & 0 & 25 & 0 & 6 & 0 & \multirow[b]{2}{*}{2,39} \\
\hline & $\%$ & $0,0 \%$ & $80,6 \%$ & $0,0 \%$ & $19,4 \%$ & $0,0 \%$ & \\
\hline
\end{tabular}

Tedarikçilerin performansına yönelik değerlendirme dahilinde, firmalara, SCOR modeli V12.0 baz alınarak Seviye 1, Seviye 2 ve Seviye 3 metriklerinden derlenen 10 adet soru yöneltilmiştir. Sorular ve cevaplarına ilişkin frekanslar ve yüzdelik dağılımlar Tablo 5'de izlenebilir. Bu tabloya göre "Sevk edilen evrak 
doğruluğu" ve "Hasarsız teslim edilen sipariş" faktörleri sırasıyla \%87,1 ve \%93,5 oranları ile en yüksek etkiye sahip iki faktör olarak karşımıza çıkmaktadır.

Tablo 5. Tedarikçi Performansına Yönelik Değerlendirme

\begin{tabular}{|c|c|c|c|c|c|c|c|}
\hline & & $\begin{array}{c}\text { Hiç } \\
\text { Etkilemez }\end{array}$ & Etkilemez & $\begin{array}{l}\text { Ne Etkiler, } \\
\text { Ne } \\
\text { Etkilemez }\end{array}$ & Etkiler & $\begin{array}{c}\text { Çok } \\
\text { Etkiler }\end{array}$ & Ortalama \\
\hline \multirow{2}{*}{$\begin{array}{l}\text { Sipariş Karşılama } \\
\text { Çevrim Zamanı }\end{array}$} & Frekans & 0 & 4 & 5 & 22 & 0 & \multirow{2}{*}{3,58} \\
\hline & $\%$ & $0,0 \%$ & $12,9 \%$ & $16,1 \%$ & $71,0 \%$ & $0,0 \%$ & \\
\hline \multirow{2}{*}{$\begin{array}{l}\text { Tam Olarak Teslim } \\
\text { Edilen Siparişlerin } \\
\text { Yüzdesi }\end{array}$} & Frekans & 0 & 1 & 2 & 28 & 0 & \multirow{2}{*}{3,87} \\
\hline & $\%$ & $0,0 \%$ & $3,2 \%$ & $6,5 \%$ & $90,3 \%$ & $0,0 \%$ & \\
\hline \multirow{2}{*}{$\begin{array}{l}\text { Mükemmel Sipariş } \\
\text { Karşılama Oranı }\end{array}$} & Frekans & 0 & 3 & 8 & 20 & 0 & \multirow{2}{*}{3,55} \\
\hline & $\%$ & $0,0 \%$ & $9,7 \%$ & $25,8 \%$ & $64,5 \%$ & $0,0 \%$ & \\
\hline \multirow{2}{*}{$\begin{array}{l}\text { Taahhüt Edilen Tarihe } \\
\text { Uygun Sevkiyat } \\
\text { Performansı }\end{array}$} & Frekans & 0 & 1 & 27 & 3 & 0 & \multirow[t]{2}{*}{3,06} \\
\hline & $\%$ & $0,0 \%$ & $3,2 \%$ & $87,1 \%$ & $9,7 \%$ & $0,0 \%$ & \\
\hline \multirow{2}{*}{$\begin{array}{l}\text { Sevkedilen Ürün } \\
\text { Doğruluğu }\end{array}$} & Frekans & 0 & 0 & 5 & 24 & 2 & \multirow{2}{*}{3,90} \\
\hline & $\%$ & $0,0 \%$ & $0,0 \%$ & $16,1 \%$ & $77,4 \%$ & $6,5 \%$ & \\
\hline \multirow{2}{*}{$\begin{array}{l}\text { Sevkedilen Adet } \\
\text { Doğruluğu }\end{array}$} & Frekans & 0 & 0 & 6 & 20 & 5 & \multirow{2}{*}{3,97} \\
\hline & $\%$ & $0,0 \%$ & $0,0 \%$ & $19,4 \%$ & $64,5 \%$ & $16,1 \%$ & \\
\hline \multirow{2}{*}{$\begin{array}{l}\text { Sevkedilen Evrak } \\
\text { Doğruluğu }\end{array}$} & Frekans & 0 & 0 & 0 & 4 & 27 & \multirow{2}{*}{4,87} \\
\hline & $\%$ & $0,0 \%$ & $0,0 \%$ & $0,0 \%$ & $12,9 \%$ & $87,1 \%$ & \\
\hline \multirow{2}{*}{$\begin{array}{l}\text { Hasarsız Teslim Edilen } \\
\text { Sipariş \% }\end{array}$} & Frekans & 0 & 0 & 0 & 2 & 29 & \multirow{2}{*}{4,94} \\
\hline & $\%$ & $0,0 \%$ & $0,0 \%$ & $0,0 \%$ & $6,5 \%$ & $93,5 \%$ & \\
\hline \multirow{2}{*}{$\begin{array}{l}\text { İade ürün dönüşlerinin } \\
\text { süreç dahilinde } \\
\text { izlenmesi }\end{array}$} & Frekans & 1 & 5 & 22 & 2 & 1 & \multirow{2}{*}{2,90} \\
\hline & $\%$ & $3,2 \%$ & $16,1 \%$ & $71,0 \%$ & $6,5 \%$ & $3,2 \%$ & \\
\hline \multirow{2}{*}{$\begin{array}{l}\text { Tedarik zinciri } \\
\text { yönetimi entegrasyonu }\end{array}$} & Frekans & 1 & 12 & 15 & 2 & 1 & \multirow{2}{*}{2,68} \\
\hline & $\%$ & $3,2 \%$ & $38,7 \%$ & $48,4 \%$ & $6,5 \%$ & $3,2 \%$ & \\
\hline
\end{tabular}

\section{B. Verilerin Analizi}

Tedarikçi firmalardan anket yolu ile toplanan veriler SPSS 24.0 paket programı yardımı ile analiz edilmiştir. Verilere uygulanan test ve analizlerin sonuçları aşağıdaki alt bölümlerde açıklanmıştır.

\section{Normallik Dağılımı}

Tedarikçi seçimini etkileyen faktörler ve tedarikçi performans kriterleri normallik dağılımı test edilmiştir. Normal dağılım hakkında bilgi sahibi olmak için Skewness (çarpıklık) ve Kurtosis (basıklık) katsayıları da incelenmiştir. Çarpıklık değerinin -2 ile +2 arasında ve basıklık değerlerinin -7 ile +7 değerleri arasında olup olmadığına bakılarak (Khine, 2013:36) ikinci bölümdeki yer alan 12 faktör üzerinde betimleyici istatistiklerin incelenmesiyle verilerin tam normal dağılım şartını sağlamamakla birlikte istatistiksel analiz için uygun olduğu anlaşılmıştır. Aynı şekilde tedarikçi performansını etkileyen faktörlere yönelik çarpıklık ve basıklık değerleri normal dağılım grafiklerine bakılarak verilerin doğru üzerine ve çok yakınına dağıldığı için normal dağıldığı söylenebilir. 


\section{Kaiser-Meyer-Olkin Testi ve Bartlett Küresellik Testi}

Faktör analizi uygunluğu ve verilerin ilişkilerinin kontrolü için KaiserMeyer-Olkin (KMO) ve Bartlett Küresellik testi yapılmıştır. Bartlett testi değeri kikare ile hesaplanır. Tedarikçi seçimini etkileyen faktörler açısından KMO değeri 0,743 hesaplanırken, Bartlett testi ki-kare değeri 161,218 olarak bulunmuş ve sonuçlar Tablo 6'da gösterilmiştir. Anlamlılık değerinin (p değeri) 0,05'in altında olması nedeni ile verilerin faktör analizine uygun olduğu tespit edilmiştir. Ayrıca KMO değerinin $(0,743) 0,70$ ile 0,80 arasında çıkması da, veri setinin faktör analizi için uygun olduğu sonucunu desteklemektedir (Aydın, 2007:5). Bartlett küresellik testi incelendiğinde anlamlılık değerinin 0,01 'den küçük olması da bizi aynı sonuca ulaştırmaktadır (Kalaycı, 2010: 322).

Tablo 6. KMO ve Bartlett Testi - Tedarikçi seçimini etkileyen faktörler

\begin{tabular}{llr}
\hline Kaiser-Meyer-Olkin (KMO) Örneklem Yeterlilik Ölçüttü & 0,743 \\
& Yaklaşık Ki-Kare & 161,218 \\
Bartlett's Küresellik Testi & df & 45 \\
& Anlamll1ık & 0,000 \\
\hline
\end{tabular}

Tedarikçi performansı açısından değerlendirildiğinde, Tablo 7 KMO ve Bartlett değerlerine yer vermektedir. KMO değerinin $0,530<0,60$ olmas1 veri setinin faktör analizi için zayıf olduğunu göstermektedir (Aydın, 2007:5). Bu sebeple faktör analizi sadece tedarikçi seçimini etkileyen faktörler üzerinde yapilacaktır.

Tablo 7. KMO ve Bartlett Testi - Tedarikçi performansını etkileyen faktörler

\begin{tabular}{|c|c|c|}
\hline \multicolumn{2}{|c|}{ Kaiser-Meyer-Olkin (KMO) Örneklem Yeterlilik Ölçütü } & 0,530 \\
\hline & Yaklaşık Ki-Kare & 111,637 \\
\hline Bartlett's Küresellik Testi & $\begin{array}{l}\text { df } \\
\text { Anlamlilik }\end{array}$ & $\begin{array}{r}45 \\
0,000\end{array}$ \\
\hline
\end{tabular}

\section{Faktör Analizi}

Çok sayıda değişkenin kaç temel değişkenle istatistiksel olarak ifade edilebileceğini inceleyen faktör analizinin yapılabilmesi için KMO değerleri incelenmiştir. Elde edilen sonuçlara göre tedarikçi performansını etkileyen faktörlere ilişkin verilerin faktör analizine uygun olmadı̆̆ 1 görülürken, tedarikçi seçimini etkileyen faktörlere ilişkin verilerin faktör analizi için elverişli olduğu belirlenmiștir.

Tablo 8'de analizi yapılan 11 faktör arasından özdeğerleri 1'den büyük olanlara bakılarak analize dahil edilecek faktör sayısına karar verilmiştir. Buna göre tedarikçi seçimini etkileyen faktörlerin 3 boyutta incelenebileceği görülmektedir. 1. bileşen ölçülen özelliğin $\% 35,843$ 'ünü ifade ederken, 2 . bileşen $\% 27,832$ 'sini ve 3. bileşen $\% 11,669$ 'unu açıklar. Toplam olarak $\% 75,344$ 'ü bu üç bileşen ile ifade edilebilir.

Tablo 8. Faktör Analizi Özdeğerler Tablosu

\begin{tabular}{|c|c|c|c|c|c|c|c|c|c|}
\hline \multirow{2}{*}{$\begin{array}{c}\text { Bile } \\
\text { şenl } \\
\text { er }\end{array}$} & \multicolumn{3}{|c|}{ İlk Özdeğerler } & \multicolumn{3}{|c|}{$\begin{array}{c}\text { Toplam Varyansın Açılklanan } \\
\text { Yüzdesi }\end{array}$} & \multicolumn{3}{|c|}{$\begin{array}{c}\text { Döndürme Sonrası Yük } \\
\text { Değerleri }\end{array}$} \\
\hline & Toplam & Varyans (\%) & $\begin{array}{c}\text { Kümülatif } \\
(\%)\end{array}$ & Toplam & $\begin{array}{c}\text { Varyans } \\
(\%)\end{array}$ & $\begin{array}{c}\text { Kümülatif } \\
(\%)\end{array}$ & Toplam & $\begin{array}{c}\text { Varyans } \\
(\%)\end{array}$ & $\begin{array}{c}\text { Kümülatif } \\
(\%)\end{array}$ \\
\hline 1 & 5,168 & 46,978 & 78 & 5,168 & 46,978 & 46,978 & 3,943 & 35,843 & 35,843 \\
\hline 2 & 2,1 & 19 & & & 19,186 & & 3,061 & 27,832 & 63,675 \\
\hline 3 & 1,010 & 9,179 & 75,344 & 1,010 & 9,179 & 75,344 & 1,284 & 11,669 & 75,344 \\
\hline
\end{tabular}




\begin{tabular}{lrrr|r|r}
4 &, 878 & 7,978 & 83,322 & & \\
5 &, 548 & 4,981 & 88,303 & \\
6 &, 446 & 4,057 & 92,360 & & \\
7 &, 268 & 2,434 & 94,794 & & \\
8 &, 245 & 2,229 & 97,023 & & \\
9 &, 205 & 1,862 & 98,885 & & \\
10 &, 123 & 1,115 & 100,000 & & \\
11 & $1,512 \mathrm{E}-15$ & $1,375 \mathrm{E}-14$ & 100,000 & & \\
\hline
\end{tabular}

Çıkarma Yöntemi: Temel Bileşen Analizi (Principal Component Analysis).

Faktörlerin neye göre 3'e ayrıldığını incelemek için döndürülmüş bileşenler matrisi (rotated component matrix) oluşturulmuştur. Bazı değişkenlerin birden fazla faktör üzerinde anlamlı olması faktörlerin adlandırılması sırasında zorluklar ortaya çıkarır. $\mathrm{Bu}$ amaçla faktörler çeşitli yöntemlerle döndürülür. En yaygın kullanılan döndürme yöntemlerinden Varimax kullanılarak döndürme işlemi gerçekleştirilmiştir (Nakip, 2013 :523).

Bir bileşenin birden fazla faktörde yüksek yük değeri vermesi ve yük değerleri arasındaki farkın 0,1 'den küçük olanlar analiz dışı bırakılarak faktör analizi tekrarlanır (Kaya, 2013). Bu şartları sağlayan bir değer bulunmadığı için hiçbir madde analiz dışı bırakılmamıştır. Her bir faktörde en yüksek değere sahip olanlar koyu yazılarak gösterilmiştir. Tablo 9 incelenirse, ilk altı değişkenin birinci faktörü (F1), sonraki dört değişkenin ikinci faktörü (F2) ve son değişkenin üçüncü faktörü (F3) temsil ettiği görülmüsştür. Birinci faktör tedarikçi seçiminde esneklik, ikinci faktör çevresel ve üçüncü faktör ise ürün değişikliği olarak adlandırılabilir. Birinci faktörün ölçülen özelliğin \%35,843 ile en yüksek olması öne çıkan boyut olarak önem kazanır.

Tablo 9. Döndürülmüş Bileşenler Matrisi Yük Değerleri

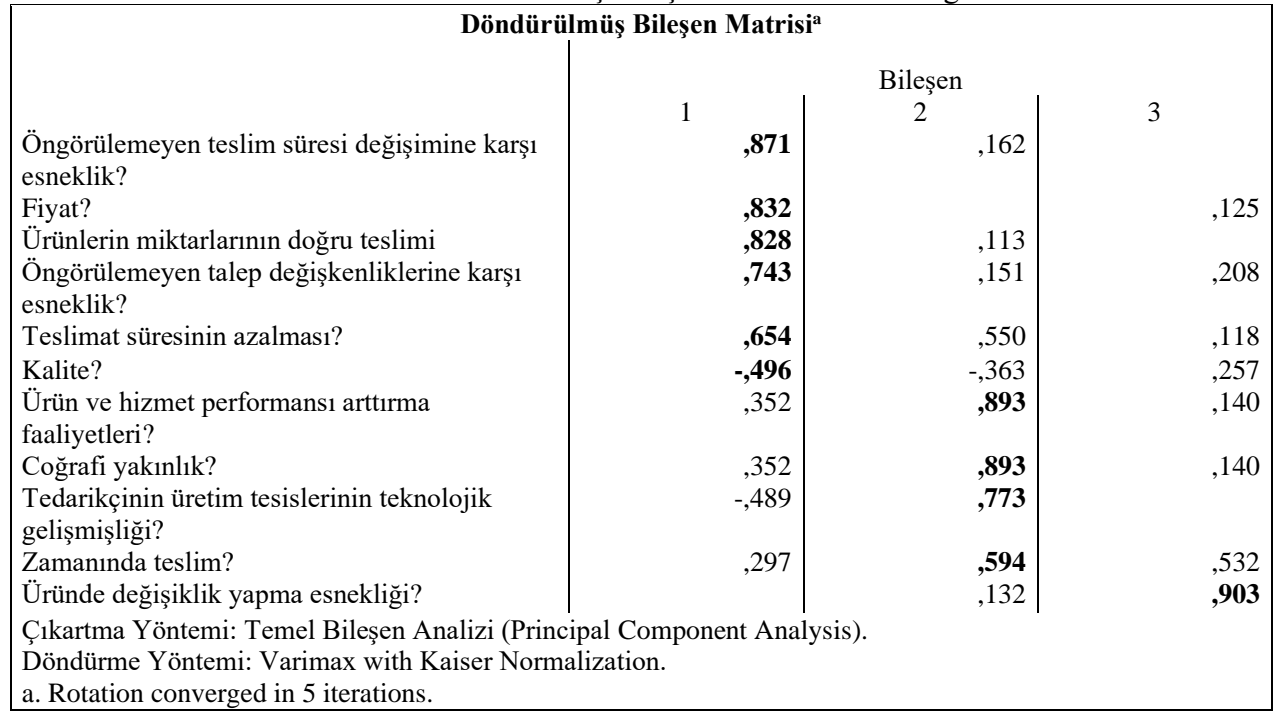

\section{Cronbach's Alpha Güvenilirlik Testi}

Cronbach's Alpha sayısı ile verilerin güvenilirliği test edilmiştir. Tedarikçi seçimini etkileyen faktörlerin Cronbach's Alpha değeri 0,789 tedarikçi performansını etkileyen faktörlerin değeri 0,700 olarak bulunmuştur. Değerlerin 
0,6 - 0,8 aralığında yer alması verilerin yüksek güvenilirliğe sahip olduğunu göstermektedir (Kalayc1, 2010: 322).

\section{Korelasyon Analizi}

Faktörler arası korelasyon matrisi Tablo 10'da görülmektedir. Korelasyon katsayıs1 -1 ile +1 arasinda olmalıdır (Bowerman vd., 2013:132). Pearson correlation ( $\mathrm{r}$ katsayıs1) katsayısı birinci ve ikinci faktör arasında 0,459 ile orta; birinci-üçüncü faktör aras1 0,187 ve ikinci-üçüncü faktör arası 0,332 olarak bulunmuştur ve faktörler arası ilişkinin zayıf olduğu söylenebilir. Çift yanlı önem seviyesi değerlerinin 0,10'dan küçük olması Pearson korelasyon sayılarının anlamlı olduğunu gösterir. Ancak burada F1'in F3'le olan korelasyon katsayisinın anlamlılık düzeyi 0,313 'tür. Bu değerin 0,10 'dan büyük olması bu katsayının istatistiksel olarak anlamsız olduğunu gösterir. Aradaki ilişki istatistiksel olarak desteklenmemektedir.

Tablo 10. Faktörler Arası Korelasyon Matrisi

\begin{tabular}{|c|c|c|c|c|}
\hline & & F1 & F2 & F3 \\
\hline \multirow[t]{3}{*}{ F1 } & Pearson Korelasyon & 1 &, $459^{* *}$ & , 187 \\
\hline & Çift yanlı önem seviyesi & & 009 & ,313 \\
\hline & $\mathrm{N}$ & 31 & 31 & 31 \\
\hline \multirow[t]{3}{*}{ F2 } & Pearson Korelasyon &, $459^{* *}$ & 1 & ,332 \\
\hline & Cift yanlı önem seviyesi & ,009 & & 068 \\
\hline & $\mathrm{N}$ & 31 & 31 & 31 \\
\hline \multirow[t]{3}{*}{ F3 } & Pearson Korelasyon & ,187 & ,332 & 1 \\
\hline & Çift yanlı önem seviyesi & ,313 &, 068 & \\
\hline & $\mathrm{N}$ & 31 & 31 & 31 \\
\hline
\end{tabular}

Tedarikçi seçim kriterlerini etkileyen faktörler ile tedarikçi performansını etkileyen faktörler arasındaki ilişki korelasyon analizi ile test edilmiştir (Tablo 11). Değişkenlerin ortalamaları alınarak tedarikçi seçimi ve performansı arasındaki ilişki incelenmiştir. Tedarikçi seçimini etkileyen faktörler ve performans arasındaki önem seviyesinin 0,448 olarak 0,10 'dan büyük olması, tedarikçi seçimi kriterleri ile performansı etkileyen faktörler arasında bir ilişkinin olmadığının göstergesidir.

Tablo 11. Korelasyon Analizi

\begin{tabular}{llrr}
\hline & & Secim_kriterleri & Performans \\
\hline Secim_kriterleri & Pearson Korelasyon & 1 &, 142 \\
& Çift yanlı önem seviyesi & &, 448 \\
& $\mathrm{~N}$ & 31 & 31 \\
\hline Performans & Pearson Korelasyon &, 142 & 1 \\
& Cift yanlı önem seviyesi &, 448 & \\
& $\mathrm{~N}$ & 31 & 31 \\
\hline
\end{tabular}

\section{Tek Örneklem (One Sample) T-Testi}

Tedarikçi seçimini etkileyen faktörlerden, "Teslimat süresinin kısalması", "Öngörülemeyen teslim sürelerine karşı esneklik" ve "Üründe değişiklik yapma esnekliği" değişkenlerinin, tedarikçi seçimini etkilemediği konusunda istatistiksel olarak anlamlı bir farkın olmadığı sonucuna varılmıştır. Yapılan analizlerde önem düzeyi $\mathrm{p}=0,05$ olarak alınmış, bu değerin altındaki veriler önemli olarak nitelendirilmiştir. 
Tedarikçi seçimini etkileyen faktörler arasında "Kalite" $(3,84)$, "Fiyat" $(3,74)$, "Ürünlerin miktarlarının doğru teslimi" $(3,35)$ ve "Öngörülemeyen talep değişkenliklerine karşı esneklik" $(3,32)$ istatistiksel olarak anlamlı olup tedarikçi seçimini etkileyen faktörlerden olduğu gözlemlenmiştir. "Coğrafi yakınlık" $(1,58)$ ve "Zamanında teslim" $(2,68)$ faktörlerinin tedarikçi seçimini etkileyen faktörlerden olmadığı gözlemlenmiştir. Bu durumun, bazı müşterinin özel olarak tercih ettiği tedarikçilerin kriterler gözetilmeksizin zorunlu olarak seçilmesinden dolayı meydana geldiği düşünülmektedir. Bu kapsamda bu kriterlerin tedarikçi seçiminde daha az etkili olduğunu düşünmek yanlış olacaktır.

Tedarikçi performansına yönelik aynı testin sonuçlarına göre "Taahhüt edilen tarihe uygun sevkiyat" ve "İade ürün dönüşlerinin izlenebilmesi" değişkenlerine verilen cevapların tedarikçi performansını etkileyip etkilemediği söylenemez. "Tam olarak teslim edilen siparişlerin yüzdesi" $(3,87)$, "Sevk edilen ürün doğruluğu" $(3,9)$, "Sevk edilen adet doğruluğu" $(3,97)$, "Sevk edilen evrak doğruluğu" $(4,87)$ ve "Hasarsız teslim edilen sipariş yüzdesi" $(4,94)$ istatistiksel olarak anlamlı olup tedarikçi performansını etkileyen faktörler olarak gözlemlenmiştir. "Tedarik zinciri yönetimi entegrasyonu" $(2,68)$ faktörü istatistiksel olarak anlamlı olmasına rağmen, ortalaması 3 puanda az olduğundan tedarikçi performansını etkileyen faktörlerden olmadığı gözlemlenmiştir.

\section{Bağımsız Grup (Independent Samples) T-Testi}

$T$ testi ile bağımlı değişkenlerden tedarikçi seçimi ve performansını etkileyen faktörleri bağlı bulunduğu iç ve dış piyasanın durumunun bağımsız değişkenlere etkisi incelenmiştir. Analiz sonuçlarına göre, tedarikçi seçimini etkileyen faktörlerden "Coğrafi yakınlık", "Zamanında teslim", "Teslimat süresinin azalması" ve "Ürün ve hizmet performansı arttırma faaliyetleri”nin, tedarikçinin bulunduğu piyasaya göre önemli bir fark gösterdiği sonucuna ulaşılmıştır. "Tedarikçinin üretim tesislerinin teknolojik gelişmişliği", "Üründe değişiklik yapma esnekliği”, "Öngörülemeyen teslim süresi değişimine karşı esneklik", "Ürünlerin miktarının doğru teslimi", "Öngörülemeyen talep değişikliklerine karşı esneklik" ve "Fiyat" faktörlerinin iç veya dış piyasada çalışma durumuna göre büyük bir fark göstermediği belirlenmiştir.

Tedarikçi performansı açısından incelendiğinde "Sevk edilen evrak doğruluğu" hariç tüm faktörlerin içinde bulunulan piyasaya göre istatistiksel açıdan anlamlı bir fark gösterdiği saptanmıştır.

\section{Tek Yönlü Varyans Analizi (Anova)}

Tedarikçi seçiminde kalitenin tedarikçilerin sektörlerine göre anlamlı bir farklılık gösterdiği sonucuna varılmıştır. "Kalite", "Fiyat", "Coğrafi yakınlık", "Tedarikçinin üretim tesislerinin gelişmişliği", "Teslimat süresinin azalması", "Üründe değişiklik yapma esnekliği" ve "Ürün ve hizmet performansını arttırma" değişkenlerinin sektörlere göre önemli olduğunu görülmektedir. Farkl1lık gösteren faktörler incelendiğinde ortalamaları yüksek olan sektörler aşağıdaki gibidir:

- Kalite: Kâğıt-Karton(4,5),Bisiklet Aksesuarları(4,08)

- Fiyat: Sele(4,75), Alüminyum(4,5)

- Coğrafi yakınlık: Alüminyum(4), Kadro(4) 
- Üretim tesisi teknolojik durumu: Alüminyum(4),Kâğıt-Karton(4)

- Teslimat süresi: Alüminyum(4), Kadro(4)

- Üründe değişiklik yapma esnekliği: Kâğ it-Karton(5), Kadro(5)

- Performans arttırma faaliyetleri: Alüminyum(4), Kadro(4)

$\mathrm{Bu}$ veriler incelendiğinde iki sektör (Alüminyum ve Kağıt-Karton) ön plana çıkmaktadır. Bu sektörlerin tedarikçileri iç piyasa tedarikçileridir. Bu durum göz önünde bulundurulduğunda iç piyasa tedarikçi seçiminde anlamlı bir farklılık gözükmektedir.

Tedarikçilerin sektörlerine göre sipariş karşılama çevrim zamanı anlamlı bir farklılık göstermediği sonucuna varılmıştır. Aynı şekilde "Taahhüt edilen tarihe uygun sevkiyat performansı", "Sevk edilen ürün doğruluğu", "Sevk edilen evrak doğruluğu", "Hasarsız teslim edilen sipariş yüzdesi" ve "Tedarik zinciri yönetimi entegrasyonu" üzerinde tedarikçilerin sektörleri arasında anlamlı bir farklılık olmadığ1 görülmüştür. Tedarikçi performansı faktörlerinden anlamlı farklılık gösteren "Tam olarak teslim edilen siparişlerin yüzdesi" faktörü incelendiğinde iki sektör hariç diğer sektörlerin ortalamaları genel ortalamanın üzerindedir. $\mathrm{Bu}$ sektörlerden (Alüminyum, Etiket, Kağıt-Karton, Lastik, Sele) müşterilerin spesifik ürünlerine göre özelleştirilmiş bileşenler tedarik edildiği göz önüne alındığında istenen miktarda teslim edilmesi, firma için büyük önem taşımaktadır.

\section{SONUÇ}

İşletmelerin tedarik zincirlerini başarılı bir şekilde yönetebilmeleri, pazarda rekabet güçlerini artıran en önemli etkenlerden biridir. Tedarik zincirinin iyi yönetilmesi, işletme için en uygun tedarikçilerin seçilmesi ve bu tedarikçilerin performanslarının etkili bir şekilde değerlendirilmesini gerektirir. Bu çalışma, kapsamında işletmelerin tedarik zincirlerini değerlendirmek üzere bir kapsamlı SCOR modeli uygulaması gerçekleştirilmiştir. Bisiklet sektöründe faaliyet gösteren bir işletmenin tedarik zinciri yönetiminde bu modele ilişkin bilgi ve kullanım düzeyini arttırmak için tasarlanmış değerlendirme soruları, SCOR modeli V12.0, Seviye 1, Seviye 2 ve Seviye 3 metrikleri dikkate alınarak hazırlanmış ve 31 tedarik zinciri üyesi tarafından cevaplandırılmıştır. Amaç, bisiklet sektöründe faaliyet gösteren işletmenin tedarik zinciri yönetiminde tedarikçileriyle ve müşterileriyle kurduğu ilişkilerin ve firmanın tedarikçi performansının, SCOR modeli kriterleri ile değerlendirilmesidir. Yapılan istatistiksel analizler sonucunda işletmenin örgüt kültürü olarak tedarik zinciri içinde yer alan paydaşlarıyla uzun vadeli ve sağlam ilişkiler kurmayı benimsediği sonucuna varılmıştır.

Araştırma kapsamında tedarikçi firma ile ilgili bilgiler toplanmış, tedarikçi seçim kriterlerini etkileyen faktörler ve tedarikçi performansını değerlendirmeye yönelik sorular yöneltilmiştir. Bu değişkenlerin analizinde normallik dağılımı test edilmiştir. Çarpıklık/basıklık değerleri karşılaştııılarak değişkenlerin normal dağılıma sahip olduğu görülmüştür.

Faktör analizi öncesi, verilerin uygunluğu Kaiser-Meyer-Olkin (KMO) testi ve Bartlett Küresellik testi ile ölçülmüştür. Tedarikçi seçimini etkileyen faktörler faktör analizine elverişli bulunarak, analiz edilmiştir. Analiz sonucunda tedarikçi seçimini etkileyen faktörler ölçeklerinin üç ana faktör kategorisinde 
toplandığ1 görülmüştür. Birinci faktör tedarikçi seçiminde esneklik, ikinci faktör çevresel ve üçüncü faktör ise ürün değişikliği olarak adlandırılabilir.

Cronbach's Alpha sayısı(0,789) ile verilerin güvenilirliği test edilmiştir. Değerlerin 0,7'den büyük olması, verilerin yüksek güvenilirliğine sahip olduğunu göstermiştir.

Kriterlerin tedarikçinin iç piyasada ya da dış piyasada faaliyet göstermesine ilişkin değişkenlikler t-testi analizi ile değerlendirilmiştir. Anlamlılık düzeyi $\mathrm{p}=$ 0,1 alınarak yapılan tek örneklem t testi ile tedarikçi seçimini etkileyen faktörler arasında "Kalite" $(3,84)$, "Fiyat' $(3,74)$,'Ürün miktarlarının doğru teslimi" $(3,35)$ ve "Talep değişkenliklerine karşı esneklik" $(3,32)$ istatistiksel olarak anlamlı bulunmuştur. "Coğrafi yakınlık" $(1,58)$ ve "Zamanında teslim" $(2,68)$ faktörlerinin farkının 3 puandan farklı olduğu istatistiksel olarak anlamlı olmasına rağmen, ortalaması 3 puanda az olduğundan tedarikçi seçimini etkileyen faktörlerden olmadığ gözlemlenmiştir. Bu durumun, bazı müşterilerin özel olarak tercih ettiği tedarikçilerin kriterler gözetilmeksizin zorunlu olarak seçilmesinden dolayı meydana geldiği düşünülmektedir. Bu kapsamda, bu kriterlerin tedarikçi seçiminde daha az etkili olduğunu düşünmek yanlış olacaktır. Tedarikçi performansına yönelik aynı test incelendiğinde; "Taahhüt edilen tarihe uygun sevkiyat" ve "İade ürün dönüşlerinin izlenebilmesi" değişkenlerine verilen cevapların istatistiksel olarak anlamlı olmadığı tespit edilmiştir. Bu bağlamda ilgili değişkenlerin tedarikçi performansını etkileyip etkilediği söylenemez. "Tam olarak teslim edilen siparişlerin yüzdesi” (3,87), "Sevk edilen ürün doğruluğu” $(3,90)$, "Sevk edilen adet doğruluğu" $(3,97)$, "Sevk edilen evrak doğruluğu" $(4,87)$ ve "Hasarsiz Teslim edilen sipariş yüzdesi" (4,94) istatistiksel olarak anlamlı olup tedarikçi performansını etkileyen faktörler olarak gözlemlenmiştir. "Tedarik zinciri yönetimi entegrasyonu"nun $(2,68)$ tedarikçi performansını etkileyen faktörlerden olmadığ 1 gözlemlenmiştir.

Bağımsız örneklem $\mathrm{t}$ testi ile tedarikçinin iç ve dış piyasada çalışma durumu araştırılmıştır. Analiz sonuçlarına göre, tedarikçi seçimini etkileyen faktörlerden "Coğrafi yakınlık", "Zamanında teslim”, "Teslimat süresinin azalması" ve "Ürün ve hizmet performansı arttırma faaliyetleri”nin, tedarikçinin bulunduğu piyasaya göre önemli bir fark gösterdiği sonucuna ulaşılmıştır. "Tedarikçinin üretim tesislerinin teknolojik gelişmişliği”, "Üründe değişiklik yapma esnekliği”, "Öngörülemeyen teslim süresi değişimine karşı esneklik”, "Ürünlerin miktarının doğru teslimi”, "Öngörülemeyen talep değişikliklerine karşı esneklik" ve "Fiyat" faktörlerinin iç veya diş piyasada çalışma durumuna göre büyük bir fark göstermediği belirlenmiştir.

Tedarikçi bilgileri arasından seçilen bağımsız değişkenlerden sektörler tek yönlü varyans analizi Anova ile test edilmiştir. Sipariş karşılama çevrim zamanının alüminyum, etiket, kadro, kağıt-karton, bisiklet aksesuarı, lastik ve sele sektörleri bazında anlamlı bir farklılığının bulunmadığı sonucuna varılmıştır. Tedarikçilerin performansına göre Anova analizi değerlendirildiğinde, sektörlere göre sipariş karşılama çevrim zamanı, taahhüt edilen tarihe uygun sevkiyat performansı, sevk edilen ürün doğruluğu, sevk edilen evrak doğruluğu ve tedarik zinciri yönetimi 
entegrasyonu açısından tedarikçilerin sektörleri arasında anlamlı bir farklılık olmadı̆̆1 görülmüştür.

SCOR modelinin, tedarik zinciri yönetimi uygulamalarına entegrasyonu öncesinde SCOR modeli metrikleri üzerine farkındalık yaratmak amaçlı olarak analizler yürütülmüştür. Analiz kapsamında bazı müşterilerin spesifik dış piyasa tedarikçi taleplerinden dolayı, dış piyasa istatistiklerinin gerçeği yansıtmadığı düşünülmektedir. İlgili firma için SCOR modelinin, iç piyasa tedarikçilerinde uygulanmasının daha doğru sonuç vereceği düşünülmektedir. İleride bu modeli uygulamayı düşünen firmalara, müşterilerin spesifik tedarikçi talep ettiği ya da ilgili sektörde tedarikçi sıkıntısı yaşanan durumlarda modelin yetersiz kaldığını göz önünde bulundurmaları tavsiye edilmektedir.

$\mathrm{Bu}$ çalışma, Lima-Junior ve Carpinetti'nin (2016) SCOR metriklerinden maliyet ve dağıtım performansı kriterlerini baz alarak gerçekleştirdikleri tedarikçi seçimi problemi yaklaşımı ve Wang vd.'nin (2018) yine SCOR metriklerinden güvenilirlik, yanıt verebilirlik, çeviklik, maliyet ve varlıklar kriterlerine dayanan tedarikçi seçimi yaklaşımı ile temelde benzerlik göstermektedir. Diğer yandan bu çalışma literatürdeki benzerlerinden farklı olarak tedarikçi seçim kriterlerinin yanında tedarikçi performansının ölçülmesine yarayan SCOR bileşenlerini de modele dahil etmektedir. $\mathrm{Bu}$ sayede SCOR modelinden elde edilen faktörlerin hangilerinin belirleyici olduğu tespit edilerek, uygulamaya konu olan firmanın çok sayıda tedarikçisi sektörel bazda incelenmiş olup, kapsamlı bir SCOR uygulama örneği ile mevcut literatüre katkıda bulunulmuştur.

\section{KAYNAKÇA}

Abou El Majd, B., Lemghari, R., Okar, C., Sarsri, D., El Ghazi, H. (2018). Benefits and limitations of the SCOR ${ }^{\circledR}$ model in Automotive Industries. MATEC Web of Conferences, 200, 00019. doi:10.1051/matecconf/201820000019

Ağar, F. (2010). Tedarik Zinciri Yönetiminde SCOR Modeli, Tedarik Süreci Performans Değerlendirmesi Ve Scorcard Uygulamast. (Yüksek Lisans Tezi), İstanbul Teknik Üniversitesi Fen Bilimleri Enstitüsü.

Apics. (2017a). APICS Supply Chain Operations Reference Model SCOR Version 12.0.

Apics. (2017b). SCOR Professional Training Retrieved from

Apics. (2017c). SCOR Quick Reference Guide Version 12.0

Apics. (2018). Understand the Structure of SCOR. Retrieved 30 Aralı 2018 http://www.apics.org/apics-for-business/benchmarking/scormark-process/scor-metrics

Aydın,Z.,Berna (2007). Faktör Analizi Yardımıyla Performans Ölçütlerinin Boyutlarının Ortaya Konulmasi. 8. Türkiye Ekonometri ve Istatistik Kongresi

Bilişik, M. E. (2012). Karşılaştırmalı Performans Analizi Modeli Ve Tedarikçi Seçimi Ve Değerlendirmesi İçin Performans Haritalarında Tedarikçi Konumlandırma. (Yüksek Lisans Tezi), İstanbul Kültür Üniversitesi, Sosyal Bilimler Enstitüsü.

Bowerman, B. L., O'Connell, R. T., Murpree, E. S., \& Orris , J. B. (2013). İsletme İstatistiğinin Temelleri. (N. Orhunbilge, M. Can, \& Ş. Er, Çev.) Ankara: Nobel AkademikYayıncılık.

Chehbi-Gamoura, S., Derrouiche, R., Damand, D., \& Barth, M. (2019). Insights from big Data Analytics in supply chain management: an all-inclusive literature review using the SCOR model. Production Planning \& Control, 1-27.

Dissanayake, C. K., \& Cross, J. A. (2018). Systematic mechanism for identifying the relative impact of supply chain performance areas on the overall supply chain performance using SCOR model and SEM. International Journal of Production Economics, 201, 102-115. 
Ganga, G. M. D., \& Carpinetti, L. C. R. (2011). A fuzzy logic approach to supply chain performance management. International Journal of Production Economics, 134(1), 177-187.

Gürsoy, Ö. (2013). Üretim Sektöründe Tedarik Zinciri Yönetimi Ve SCOR (Tedarik Zinciri Operasyonları Referans Modeli) Modelinin Farkındalık Düzeyi Üzerine Bir Araştırma. (Yüksek Lisans Tezi), Adnan Menderes Üniversitesi, Sosyal Bilimler Enstitüsü.

Kalaycı. Ş. (2010). SPSS Uygulamalı Çok Değişkenli İstatistik Teknikleri. Ankara:Dinamik Akademi Yayıncilik

Karahan, A., ve Özgür, E. (2009). Stratejik yönetim modeli olarak kurumsal karnenin uygulanabilirliği. SÜ İ̈BF Sosyal ve Ekonomik Araştırmalar Dergisi, 10(16), 59-81.

Kaya, M. F. (2013). Sürdürülebilir Kalkınmaya Yönelik Tutum Ölçeği Geliştirme Çalışması. Marmara Coğrafya Dergisi, 28, 175-193.

Khine, S. M. (2013). Application of Structural Equation Modeling in Educational Research and Practice. Rotterdam:Sense Publishers

Kocaoğlu, B. (2009). Tedarik Zinciri Performansı Ölçümü Iç̧in Stratejik Ve Operasyonel Hedefleri Bütünleştiren SCOR Modeli Temelli Bir Yapı. (Doktora Tezi), Yıldız Teknik Üniversitesi, Fen Bilimleri Enstitüsü.

Li, L., Su, Q., \& Chen, X. (2011). Ensuring supply chain quality performance through applying the SCOR model. International Journal of Production Research, 49(1), 33-57.

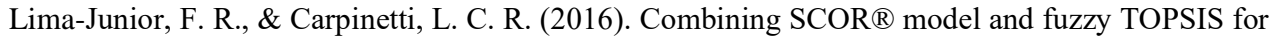
supplier evaluation and management. International Journal of Production Economics, 174, 128-141.

Lockamy, A., \& McCormack, K. (2004). Linking SCOR planning practices to supply chain performance. International journal of operations \& production management.

Nakip, M. (2013). Pazarlamada Araştırma Teknikleri ve SPSS Uygulamaları. Seçkin Yayıncılık

Ntabe, E. N., LeBel, L., Munson, A. D., \& Santa-Eulalia, L. A. (2015). A systematic literature review of the supply chain operations reference (SCOR) model application with special attention to environmental issues. International Journal of Production Economics, 169, 310-332.

Palma-Mendoza, J. A. (2014). Analytical hierarchy process and SCOR model to support supply chain re-design. International journal of information management, 34(5), 634-638.

Persson, F. (2011). SCOR template-A simulation based dynamic supply chain analysis tool. International Journal of Production Economics, 131(1), 288-294.

Sağlam, A. A. (2013). Tedarik Zinciri Yönetiminde SCOR Modeli ve SCORCARD Uygulamast. (Yüksek Lisans Tezi), Bahçeşehir Üniversitesi, Fen Bilimleri Enstitüsü.

Tunçbilek, F. (2012). Tedarik Zinciri Yönetiminde SCOR Modeli Ve Lastik Sektörü Uygulaması. (Yüksek Lisans Tezi), Kocaeli Üniversitesi, Fen Bilimleri Enstitüsü.

Zhou, H., Benton Jr, W. C., Schilling, D. A., \& Milligan, G. W. (2011). Supply chain integration and the SCOR model. Journal of Business Logistics, 32(4), 332-344.

\section{SUMMARY}

The supply chain is a network of facilities that supply raw materials, transform them into intermediate goods, and then final products, and deliver products to customers through a distribution system. Companies may achieve their goals in an intense competitive environment only with integrated supply chain management that is successfully planned and implemented. Developed by the Supply Chain Council to provide a reference to supply chain operations, the SCOR model provides a standard definition of management processes, a framework of relationships between standard processes, standard metrics to measure process performance, best-in-class performance management applications, and software features and functions. The supply chain performance metrics defined in SCOR model are reliability, responsiveness, agility, costs and assets. The supply chain is called well performed, if the criteria related to these metrics is satisfied by supply 
chain members. The Supply Chain Council defines more than 250 SCOR metrics for evaluation of supply chains. The selection of these metrics depend on the nature and the aims of the supply chain.

In this paper, a model based on SCOR metrics is introduced to determine the factors affecting supplier selection and evaluate supplier performance. The reasons for the selection of the SCOR model as the evaluation method in the study can be expressed with the following benefits of the model:

- It provides a common communication language.

- It measures the performance of processes successfully

- It utilizes the information technologies

- It is helpful in uniting the employees on a common goal and creating a corporate culture

- It defines, measures and evaluates the entire supply chain.

A case study was implemented in the supply chain of a company which manufactures bicycles. The company has more than 100 suppliers, 31 of which was included in this study. A questionnaire survey was conducted with these suppliers. The supplier companies are asked two set of questions. The first set aims to understand the decisions about the question: "What are the important factors effecting supplier selection?" The second set aims to clear the answer of the problem: "What are the main performance criteria for evaluating the suppliers?" The companies were given 11 factors for the first set and 10 factors for the second. The answers are analyzed by using SPSS 24.0 software program.

According to the results of the study, the most important factors for supplier selection in the supply chain under consideration can be listed as "flexibility to change in products", "reduction in delivery time" and "flexibility against change in delivery time", respectively. The factors that affect supplier performance the most are determined as "traceability of returned products and "on time delivery".

Before the integration of the SCOR model into supply chain management applications, analyzes were conducted to create awareness on the SCOR model metrics. Within the scope of the analysis, it is thought that the foreign market statistics do not reflect the reality due to the specific foreign market supplier demands of some customers. It is considered that the implementation of the SCOR model for the relevant company in domestic suppliers will yield more accurate results. In the future, companies considering the implementation of this model are recommended to take into account that the model is inadequate in cases where customers demand specific suppliers or if there is a supplier shortage in the relevant sector.

This study has a similar approach with the studies by Lima-Junior and Carpinetti (2016), and Wang et al. (2018) on supplier selection process based on SCOR metrics. On the other hand, unlike its counterparts, this study includes SCOR components that are used to measure supplier performance as well as supplier selection. Thus, this study contributes to existing literature by providing a comprehensive application of SCOR model analyzing a vast number of suppliers. 